\title{
Gender Earnings and Part-Time Pay in Australia: 1990-1998
}

\author{
Alison Preston \\ Women’s Economic Policy Analysis Unit \\ Curtin University of Technology
}

Discussion Paper Number 26

March 2003

Women's Economic Policy Analysis Unit (WEPAU), Curtin Business School, Curtin University of Technology GPO Box U1987, Perth 6845.

http://www.cbs.curtin.edu/research/wepau/ 


\title{
Gender Earnings and Part-Time Pay in Australia: 1990-1998
}

\begin{abstract}
In October 1991 significant changes were made to the Australian industrial relations system aimed at giving primacy to enterprise (decentralized) bargaining and introducing more flexibility into the system. It was widely predicted that the changes would adversely impact on the relative pay position of women and of part-time workers, in particular. Between 1990 and 1998, however, the gross gender wage ratio amongst full-time employees converged four percentage points to 88.8 per cent; corresponding convergence in the part-time labour market was equal to 10.3 percentage points. Decompositions reported in this paper show that the convergence in the part-time labour market derived from compositional shifts; the entry of less qualified and less experienced males into part-time employment. Wage effects, specifically the experience of faster wage growth for women relative to men, explain observed convergence in the full-time labour market. A number of possible reasons for the latter, including the potentially negative effects of deunionization on male wages, are advanced in the paper.
\end{abstract}

\section{Introduction}

In October 1991 significant changes were made to the Australian industrial relations system aimed at giving primacy to enterprise (decentralized) bargaining and introducing more flexibility into the system. At the time concerns were expressed about the likely impact such developments would have on the relative pay position of women and other target equity groups such as part-time workers. A number of empirical studies had demonstrated a significant link between the size of the gender wage gap and the prevailing bargaining structure, with centralized bargaining typically associated with smaller gaps (Gregory and Daly 1992; Blau and Kahn 1992; Whitehouse 1992).

Since the adoption of enterprise bargaining in 1991 the Australian wage structure has changed, although not entirely in the manner predicted. Between 1990 and 1998 the gross gender wage ratio in the full-time labour market converged by four percentage points (to 88.8 per cent). In the part-time labour market the same ratio converged by 10.3 percentage points (to 103.1 per cent). Given the literature concerning systems of pay determination and gender equity these trends are curious, although not unique (see Bernhardt, Morris and Handcock 1995; Bruegel and Perrons 1998; and Bell and Ritchie 1998).

There is now growing consensus that the gender pay gap is a 'morphing beast' (Pocock 1991: 1), affected as it is by a number of counterbalancing forces including: the institutional features of the wages system (as noted above), human capital considerations (Preston 1997); the overall wage structure (Blau and Kahn 1996) and patterns of wage 
inequality (Bernhardt et al. 1995; Whitehouse 2001). Aggregate data, therefore, present a poor reflection of the underlying causes and trends of gender pay differences.

In this paper data covering the period 1990 to 1998 (i.e. pre and post the adoption of more decentralised bargaining) are used to disaggregate observed trends in Australia and shed further insight into the debate over institutions (bargaining structures) and gender wages. A central question in the investigation is that of 'male gains or female losses?'. Within the literature there is increasing concern that observed gains in the relative pay position of women have been underpinned by a deterioration in the economic position of men (Bruegel and Perrons 1998).

Whilst the empirical approach employed in this paper is not new, a number of beneficial features of this study are worth highlighting. First, in undertaking a 'within' country analysis this paper overcomes problems faced in cross-country comparative studies, such as differing historical, cultural characteristics as well as other features of the bargaining systems (such as levels of coordination) (Flanagan 1999). The second advantage lies in the fact that the unit record data employed in the paper allow the computation of hourly wages and, thus, a study of part-time workers.

The paper is organised as follows. Section 2 provides a brief overview of developments with respect to wage fixing in Australia. Section 3 deals with matters of method and definition. Section 4 presents the results. Section 5 concludes the paper and offers some directions for future research.

\section{Background: Changing Australian Bargaining Structures}

It is well known that arrangements for the conduct of collective bargaining vary substantially among countries. Important determinants include institutional structures, union density rates, political climate, ideologies and cultural norms (Flanagan 1999). In Japan and the US, for example, most negotiations take place at the company or workplace level. Centralized bargaining is characteristic of Scandinavian countries and, throughout much of the last century, Australia and New Zealand as well.

In the late 1980s Australia, in responding to growing pressure from the business lobby, embarked on a set of reforms designed to deregulate the labour market and decentralize the level of wage determination. The first major shift in this direction came in October 1991 when the Australian Industrial Relations Commission (AIRC), the peak industrial tribunal in Australia, adopted the 'Enterprise Bargaining Principle' (EBP) as a basis for wage fixation. Under this principle wage adjustments could only be accessed if parties reached (and formalized) an enterprise (union negotiated) collective agreement. The initial uptake of enterprise bargaining was slow reflecting, in part, the prescriptive requirements of the EBP (Preston 2001a: 74-75). Additional reforms were introduced in 1993 to further promote and encourage enterprise, although the next major shift in direction came in 1996 in the form of the Workplace Relations Act (WRA). 
In a radical departure from the traditional system of collective bargaining in Australia, the WRA introduced, for the first time in the Federal jurisdiction, the option of individual bargaining (in the form of Australian Workplace Agreements (AWAs)). Although primacy was given to enterprise (collective) bargaining (which, by now could also be without unions) the option of individual bargaining legitimized individual level negotiation over employment conditions and wages (Creighton and Stewart 2000, cited in Deery, Plowman, Walsh and Brown 2001: 285).

In seeking to affect (limit) the bargaining scope and give primacy to enterprise bargaining the WRA reduced the scope of Awards (traditional instruments for regulating the employment relationship) to 20 allowable matters, relegated the Award system to a set of minimum 'safety-net' standards to be improved upon via enterprise bargaining, and removed the requirement for a public interest test on certified agreements coming before the AIRC for registration (Deery et al 2001: 259-261). (Two state jurisdictions, Victoria and Western Australia had earlier (1992 and 1993, respectively) introduced individual level bargaining and other reforms to deregulate the labour market.

By the end of the 1990s the Australian bargaining system was highly fragmented and wage negotiations occurred at a variety of levels (see Table 1). Just under a quarter of the total workforce (23.2 per cent) were entirely reliant on the Award and, thus, the determinations of the AIRC for their wage outcomes and adjustments. A substantial proportion of employees (36.8 per cent) relied on collective bargaining (with outcomes detailed in collective agreements) for the fixation of their wages. Limited use was made of registered (i.e. formal) individual agreements with only 1.8 per cent of employees

TABLE 1

Methods of Pay Setting, Australia, May 2000

\begin{tabular}{|l|c|c|c|c|}
\hline & Awards Only & $\begin{array}{l}\text { Collective } \\
\text { Agreements }^{(a)}\end{array}$ & $\begin{array}{l}\text { Individual } \\
\text { Agreements }^{(b)}\end{array}$ & Total \\
\hline & \multicolumn{4}{|c|}{ Proportion of Employees (\%) } \\
\hline Males & \multicolumn{3}{|c|}{} & \\
\hline Full-time employees & 12.4 & 37.5 & 50.1 & 100.0 \\
\hline Part-time employees & 37.4 & 33.3 & 29.3 & 100.0 \\
\hline All employees & 16.8 & 36.7 & 46.5 & 100.0 \\
\hline Females & & & 41.8 & 100.0 \\
\hline Full-time employees & 19.9 & 38.3 & 24.1 & 100.0 \\
\hline Part-time employees & 40.8 & 35.1 & 33.3 & 100.0 \\
\hline All employees & 29.9 & 36.8 & & \\
\hline Persons & & & 47.0 & 100.0 \\
\hline Full-time employees & 15.3 & 37.8 & 25.5 & 100.0 \\
\hline Part-time employees & 39.9 & 34.6 & 40.0 & 100.0 \\
\hline All employees & 23.2 & 36.8 & & \\
\hline
\end{tabular}

Table 24: ABS Cat. 6305.0. May 2000.

(a) includes registered and unregistered collective agreements; (b) includes registered and unregistered individual agreements. 
determining their wages under this instrument. Informal individual agreements, however, extended to 38.2 per cent of the workforce. Many (possibly the majority) of these agreements would have been common law contracts, in other words outside the bargaining system (Peetz 2001). A substantial proportion of the balance would have been over-Award agreements, informal arrangements to pay over the minimum rates specified within the Award. ${ }^{1}$

There is a gender dimension to the patterns discussed above. As shown in Table 1, the Award (and only the Award) determines the pay for 29.9 per cent of all female employees and 16.8 per cent of all male employees. The Award is also more likely to be used to fix the wages of part-timers than full-timers. As shown in Table 1, 39.9 per cent of all part-timers (men and women) have their pay set by the Award; the corresponding share amongst full-time workers is 15.3 per cent.

Patterns of wage Award and agreement coverage also differ between sectors; 83.2 per cent of public sector employees have their pay determined by collective agreement. In the private sector the corresponding share is 22.3 per cent. Individual agreements (be it an informal over-award agreement, common law contract, or formal individual agreement) are more prevalent in the private sector, although interestingly, the penetration of AWAs (formalized individual agreements in the federal jurisdiction) has been highest within the most unionized sectors. Peetz (2002: 41-42) argues that the latter reflects a managerial strategy designed to weaken trade union power and influence. If trade union membership statistics are anything to go by then Peetz may be correct. In 2000 the density rate was equal to 24.7 per cent, down from 39.6 per cent in 1992.

The significance of the above developments, as they related to this paper, is that the wage adjustments within in each stream differ markedly. While adjustments in the Award stream (as determined by the AIRC) saw growth rates of around 1.5 per cent (below the $\mathrm{CPI}$ ), average increases contained in collective agreements around the same time were in the 4 to 4.5 per cent range (Preston 2001b). The markedly different outcomes reflect, in part, the will of the federal government and their insistence that "... arbitrated safety net adjustments not [to] act as a disincentive to agreement making”. (DEWRSB 2001: 98).

Given the over-representation of women and part-time workers in the Award stream and the fact that the average wage growth rate within this stream has lagged behind that recorded in the bargaining stream, a priori one would expect the changes to lead to a deterioration in the pay position of women and part-timers relative to men employed fulltime.

In the remainder of this paper unit record data from 1989/90 (when wage fixing primarily occurred at the national and industry level) and 1997/98 (a period marked by fragmented bargaining structures) are used to study the evolving wage structure and, in particular, understand trends in the gender wage gaps earlier reported. 


\section{Data and methodology}

In contemporary economic literature a dominant framework for the study of wage determination is the human capital model. The model may be stated algebraically as follows:

$\ln \hat{Y}_{i}=\hat{\beta}_{0}+V_{i} \hat{\beta}_{i}$

where $\ln Y$ denotes the natural logarithm of hourly earnings, $V$ is a vector of human capital characteristics known to affect wages (e.g. qualifications, labour market experience, and

demographic characteristics); and $\hat{\beta}$ is a vector of estimated slope coefficients associated with these characteristics. The latter provides a measure of the rates of return to the characteristics controlled for in the wage equation. (For a detailed derivation of the human capital model see Preston 2001a: 10-14).

Equation (1) is estimated using data from the 1989/90 Income Distribution Survey (90IDS) and the 1997/98 Survey of Income and Housing Costs (formerly the IDS) (98-IDS). The advantages of these data have been noted earlier, however, there are some limitations which should be canvassed here. The limitations essentially surround the extent to which comparisons from this study may be made with (official) published data from the Australian Bureau of Statistics (ABS).

Hourly wage data published by the ABS are restricted to non-managerial employees and measure the common ratio of the weekly wage divided by the weekly hours paid for. In this study hourly wages are derived using a divisor that measures total hours worked and the sample includes managerial and non-managerial workers (there is no way of distinguishing between these two groups in this study). ${ }^{2}$ The sample is, however, restricted to those with one job on account of the fact that the hourly wages in second (and subsequent jobs) could not be derived.

Of perhaps more significance is the absence of information on when the hours were worked (a limitation shared by many data sets) and/or components in the total wage package. The derived hourly wage rate may, therefore, be: inflated on account of loadings for shift work and/or unsociable hours; or understate the actual remuneration level if the recent trend towards more innovative remuneration packages has seen the introduction of more non-wage benefits such as superannuation, care, housing and health insurance. Whilst these are acknowledged limitations they are, nevertheless, ones that are shared by all other available unit record data sets in Australia.

Sample size and model specification After purging the data sets of observations with missing information on key variables in the chosen model and, as noted above, restricting the samples to persons employed in only one job, there were 12761 observations in the 90-IDS and 6155 observations in the 1998-IDS. 
The estimating approach uses ordinary least squares (OLS). The Breusch-Pagan (BP) test is used to detect whether or not heteroskedasticity is present and, where detected, White's (1980) technique is used to correct the standard errors. The set of independent variables (i.e. the vector $V$ ) includes a three dummy variables capturing highest level of formal education (completed high school to Year 12 (highest level), completed a vocational or trade certificate, completed a bachelor degree or higher; the benchmark group consists of those who did not complete high school to Year 12.

Labour market experience is controlled for via the traditional Mincer (1974) proxy approach which measures potential experience as age minus years of schooling minus 5 (assumed age when schooling commenced). It is entered in the model in the quadratic form. In the literature it is generally acknowledged that this measure is a poor proxy for female labour market experience on account of their intermittent labour market activity. It is also acknowledged that it is an increasingly poor proxy for male labour market experience given their changing patterns of employment. Given these limitations, and in particular those related to female experience patterns, additional controls in the form of marital status (two dummies, one controlling for marriage and another capturing those who are either widowed/separated/divorced, with the never married forming the benchmark group) and children (equal to 1 if the individual has children) dummies are also entered into the model. These controls help capture some of the labour market interruptions that women face on account of marriage and family responsibilities. Other determinants known to affect wages and controlled for in this study include birthplace (equal to 1 if the individual was born overseas) and geographic location (equal to 1 if individual lives in a city or metropolitan area).

Following Wooden (1999) a series of hour-related dummy variables are also included to capture any effect of unpaid overtime hours on observed wages (one dummy captures the effects on wages of working 45-49 hours per week; a second captures the effect of every long hours (50 or more hours per week) and a third measures the effect on very short hours of work (less than 10 hours per week). Whilst the inclusion of hours of work as an explanatory variable may generate a spurious result in that the dependent variable is constructed using hours of work, the literature does demonstrate the importance of controlling for long and short hours of work (see Preston 1997; and Wooden 1999).

\section{Method}

Pooled equations using the above model specification are estimated with additional dummy variables capturing gender and employment status (full-time / part-time) included. The results from this stage are reported in Table 2 and discussed below. The models are also estimated separately for four groups of employees: women employed full-time; men employed full-time; women employed part-time and men employed parttime. In total there are eight sets of results (four for each time period). Following an approach previously used by Blau and Kahn (1997:29) these results are then employed to study the separate role played by compositional (human capital) shifts and wage effects in the production of changed wage relativities. In other words, the approach allows us to ask the question: 'If the composition of the workforce in 1990 had remained unchanged what might the wage relativities look like in 1998 and how, if at all, would they differ 
from relativities prevailing in 1990?'. The answer to the latter shows the extent to which wage effects (unrelated to changing human capital returns) have affected the changing wage structure over the 1990s. The human-capital constant (or composition-constant) predicted average wage is estimated by combining the coefficients $\left(\hat{\beta}_{i}\right)$ estimated from the 1998 wage equation with the measured characteristics or means $\left(\bar{V}_{i}\right)$ from the equivalent 1990 wage equation. One may similarly examine the separate contribution of compositional shifts to movements in the wage structure by holding the rates of return constant at 1990 levels. The results from this exercise (reported in Table 3) are also discussed below.

\section{Results \& Discussion}

The estimates derived from an estimation of the wage equation as specified at equation (1) above are recorded in Table 2. Whilst the explanatory power of the model is relatively low (equal to 17.9 per cent in 1998) it is noteworthy that such power is observed in other similar studies, as is the pattern of falling explanatory power, down from 26.5 per cent in 1990 (see Le and Miller, 2001: 39).

In both periods studied (1990 and 1998) the education, labour market experience, hours of work, marital status, birthplace, are important drivers of observed wage outcomes. For example, in 1990 degree holders earned around 47 per cent more than their unqualified counterparts; by 1998 the corresponding premium had fallen 6 percentage points to 41 per cent (a statistically significant change). Persons residing in the metropolitan area earn around six per cent more than their rural and regional counterparts. Marriage is similarly associated with a wage premium, which in 1990 was 11.6 per cent. By 1998 the premium had fallen 3.8 percentage points to 7.8 per cent. Estimated signs on the long and short hour dummy variables are also consistent with other studies, with long hours of work attracting a wage penalty and short hours of work a wage premium (e.g. Preston 1997; and Wooden 1999).

The results also illustrate the presence of significant wage gaps, although relative to men employed full-time the pay position of women appears to have improved. In Table 2 dummy variables controlling for gender and employment status (part-time / full-time) provide a measure of the adjusted wage gaps relative to males employed full-time. ${ }^{3}$ In 1998, for example, the adjusted gender wage gap in the full-time labour market was equal to 10.1 per cent, significantly lower than the 13 percentage point gap recorded in 1990 . Similarly, in 1990 women employed part-time earned 14.5 per cent less than men employed full-time; by 1998 this gap was equal to 7.4 per cent. In both periods the adjusted part-time/full-time (persons) wage gap was relatively similar at around 8 per cent. 
TABLE 2: Australia 1990 \& 1998 ‘Main Job’ Wage Equations (dependent variable: ln(hourly earnings))

\begin{tabular}{|c|c|c|c|c|c|c|c|c|}
\hline & & & & & & & & \\
\hline & Coeff. & t-statistic & Coeff. & t-statistic & Coeff. & t-statistic & Coeff. & t-statistic \\
\hline Female-employed full-time & -0.130 & (18.710) & -0.101 & (8.318) & $\mathrm{a}$ & a & a & $\mathrm{a}$ \\
\hline Male-employed part-time & -0.015 & $(0.540)$ & -0.064 & $(1.932)$ & a & a & $\mathrm{a}$ & $\mathrm{a}$ \\
\hline Female-employed part-time & -0.145 & $(5.147)$ & -0.074 & (2.028) & a & a & a & a \\
\hline Part-time employee & a & $\mathrm{a}$ & a & a & -0.089 & $(9.070)$ & -0.081 & (5.499) \\
\hline Highest level of Education & & & & & & & & \\
\hline High school (Year 12) & 0.118 & (11.491) & 0.086 & (3.570) & 0.126 & (12.077) & 0.071 & (2.913) \\
\hline Vocational Certificate & 0.205 & (26.113) & 0.160 & (11.636) & 0.209 & (26.345) & 0.169 & (12.315) \\
\hline Bachelor Degree (or Higher) & 0.469 & (41.074) & 0.409 & $(25.084)$ & 0.471 & 40.532 & 0.403 & (24.614) \\
\hline Labour Market Experience & & & & & & & & \\
\hline Potential experience & 0.029 & (26.018) & 0.029 & $(13.803)$ & 0.029 & (25.284) & 0.028 & (13.859) \\
\hline (Potential experience squared)/100 & -0.059 & (22.162) & -0.055 & (11.307) & -0.056 & (20.839) & -0.053 & (11.155) \\
\hline Hours worked per week & & & & & & & & \\
\hline 45-49 hours & -0.037 & (3.591) & -0.011 & $(0.596)$ & -0.020 & (1.851) & 0.004 & $(0.214)$ \\
\hline 50 hours or more & -0.050 & (4.754) & -0.053 & (2.923) & -0.022 & (2.114) & -0.032 & $(1.741)$ \\
\hline Less than 10 hours & 0.279 & (9.386) & 0.300 & $(5.770)$ & 0.285 & (9.566) & 0.304 & (5.833) \\
\hline Marital Status & & & & & & & & \\
\hline Married & 0.116 & (12.352) & 0.078 & (4.713) & 0.105 & (11.133) & 0.071 & $(4.282)$ \\
\hline Widowed, separated, divorced & 0.064 & (4.215) & 0.035 & $(1.432)$ & 0.033 & (2.169) & 0.017 & $(0.690)$ \\
\hline Has a dependant child & -0.016 & (3.231) & -0.005 & $(0.566)$ & -0.006 & $(1.222)$ & 0.000 & $(0.001)$ \\
\hline Born overseas & -0.039 & (5.189) & -0.002 & $(0.134)$ & -0.037 & $(4.824)$ & -0.001 & $(0.110)$ \\
\hline Resides in a metropolitan area & 0.069 & (9.378) & 0.056 & (4.589) & 0.064 & (8.578) & 0.053 & (4.373) \\
\hline Constant & 2.004 & $(171.251)$ & 2.233 & $(109.661)$ & 1.952 & (171.536) & 2.197 & (116.536) \\
\hline Adjusted $\mathrm{R}^{2}$ & 0.265 & & 0.179 & & 0.246 & & 0.171 & \\
\hline Dependent Variable Mean & 2.448 & & 2.674 & & 2.448 & & 2.674 & \\
\hline Breuch-Pagan Statistic & 1844.5 & & 1161.6 & & 1720.2 & & 1109.5 & \\
\hline Sample size & 12761 & & 6155 & & 12761 & & 6155 & \\
\hline
\end{tabular}

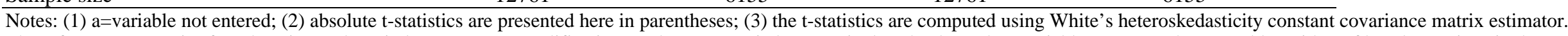

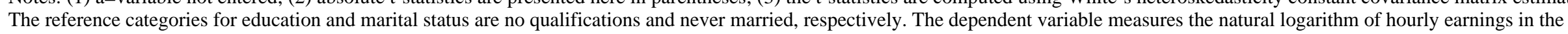
main job. The sample is restricted to wage and salary earners aged between 15 and 64 who work for one employer. Persons with two or more jobs are excluded from the sample. 
One story suggested by these data is that the Australian industrial relations reforms have not disadvantaged women in either full-time or part-time employment. Indeed, in spite of concerns, women appear to have performed relatively well. Research elsewhere, however, cautions against, the benign story told by aggregate data (Whitehouse 2001). Decompositions presented in Table 3 are, therefore, used to further comprehend the underlying trends. Discussion concentrates, first, on the role, if any, played by compositional shifts in the workforce. Thereafter attention shifts to the role of wage effects, in other words, wage adjustments which are unrelated to compositional effects.

TABLE 3

Australia Actual and Predicted Mean Gross Log Wage (main job)

\begin{tabular}{lccc}
\hline & 1990 & 1998 & $\begin{array}{c}1990-98 \\
\text { Log Point } \\
\text { Change }\end{array}$ \\
\hline Males: Employed Full-Time & & & \\
Actual Wage & 2.512 & 2.732 & 0.220 \\
Human-capital-Constant (1990 means) & 2.512 & 2.701 & $\mathbf{0 . 1 8 8}$ \\
Rate-of-Return-Constant (1990 coefficients) & 2.512 & 2.541 & 0.029 \\
Females: Employed Full-Time & & & \\
Actual Wage & 2.360 & 2.620 & 0.260 \\
Human-capital-Constant (1990 means) & 2.360 & 2.582 & $\mathbf{0 . 2 2 2}$ \\
Rate-of-Return-Constant (1990 coefficients) & 2.360 & 2.384 & 0.024 \\
Males: Employed Part-Time & & & \\
Actual Wage & 2.463 & 2.585 & 0.122 \\
Human-capital-Constant (1990 means) & 2.463 & 2.690 & $\mathbf{0 . 2 2 8}$ \\
Rate-of-Return-Constant (1990 coefficients) & 2.463 & 2.416 & -0.047 \\
Females: Employed Part-Time & & & \\
Actual Wage & 2.390 & 2.616 & 0.226 \\
Human-capital-Constant (1990 means) & 2.390 & 2.619 & $\mathbf{0 . 2 2 9}$ \\
Rate-of-Return-Constant (1990 coefficients) & 2.390 & 2.379 & -0.011 \\
\hline
\end{tabular}

Notes: Human-capital constant predicted wages for 1998 are estimated holding 1990 means constant and allowing rates-of-return to vary (i.e. combine 1998 coefficients with 1990 means); Rate-of-return-constant predicted wages for 1998 are estimated holding 1990 coefficients constant and allowing means to vary (i.e. combining 1998 means with 1990 coefficients).

Compositional effects, as noted earlier, are derived by holding the rate of return constant at 1990 levels and allowing the human capital characteristics of the workforce to vary over the period 1990 to 1998. The results associated with this decomposition show that real wage growth amongst male and female full-time workers would have been fairly similar, equal to 0.029 and 0.024 log points, respectively. The story amongst persons employed part-time is, however, different. Estimates show that compositional shifts on their own would have delivered a real wage fall (measured in log points) of 0.047 to men and 0.011 to women. In other words, compositional shifts (in the form of lower average levels of education and experience) underpin the deterioration in the relative pay position of persons employed part-time, with the deleterious effects greater for men than women. Compositional shifts, however, do not explain observed wage patterns within the fulltime labour market. 
The wage effect is derived by holding the composition of the workforce constant at 1990 levels and allowing the rate of return to vary over the period 1990 to 1998 . In the fulltime labour market the decomposition shows that between 1990 and 1998 the nominal wages of men and women would have grown by 0.188 and $0.222 \log$ points, respectively. In other words, female wage growth would have outstripped male wage growth. In the part-time labour market men and women would have experienced nominal wage growth, equal to 0.228 and $0.229 \log$ points, respectively. Taken together the results show that between 1990 and 1998 women employed full-time and part-timers (men and women) experienced nominal wage growth of between 0.222 and 0.229 log points after compositional shifts were controlled for. The corresponding wage growth for men employed full-time was slower, equal to 0.188 log points.

Observed convergence in the gender pay gap in the full-time labour market is thus underpinned by wage effects which have been less favourable for men. Table 4 helps illustrate this argument. In 1990 the common ratio of female and male average hourly wages was equal to 84.8 per cent in the full-time labour market. By 1998 this gross gender wage gap had narrowed by four percentage points to 88.8 per cent. If, on the one hand, there had been no change in the rates of return in the labour market the gender wage ratio in 1998 would have been 84.3 per cent, essentially unchanged. On the other hand, if the rates of return were allowed to vary and the composition of the workforce had remained unchanged at 1990 levels, the gender wage ratio in 1998 would have been 88.1 per cent, a convergence of 3.3 percentage points. The wages of women in full-time employment would have grown faster than those of males in full-time employment and the gender wage gap would, as a result, have narrowed.

TABLE 4

Actual and Predicted Gross Mean Wage Ratios (main job)

\begin{tabular}{|c|c|c|c|c|c|c|c|}
\hline & \multirow{2}{*}{$\begin{array}{c}1990 \\
\\
\text { Actual } \\
\% \\
\end{array}$} & \multicolumn{3}{|c|}{1998} & \multicolumn{3}{|c|}{ \%-point change relative to 1990 ratio } \\
\hline & & $\begin{array}{c}\text { Actual } \\
\% \\
\end{array}$ & $\begin{array}{c}\text { Return } \\
\text { constant } \\
\% \\
\end{array}$ & $\begin{array}{c}\text { capital } \\
\text { constant } \\
\%\end{array}$ & $\begin{array}{l}\text { Actual } \\
\text { (1998) }\end{array}$ & $\begin{array}{c}1998 \\
\text { Composition } \\
\text { Effect }\end{array}$ & $\begin{array}{l}1998 \\
\text { Wage } \\
\text { Effect }\end{array}$ \\
\hline GWR (full-time) & 84.8 & 88.8 & 84.3 & 88.1 & 4.0 & -0.5 & 3.3 \\
\hline GWR (part-time) & 92.8 & 103.1 & 96.3 & 92.8 & 10.3 & 3.5 & 0.0 \\
\hline $\begin{array}{l}\text { Males: PT/FT wage } \\
\text { ratio } \\
\text { Females-PT / }\end{array}$ & 95.0 & 85.3 & 87.5 & 99.0 & -9.7 & -7.5 & 4.0 \\
\hline $\begin{array}{l}\text { Males-FT wage } \\
\text { ratio. } \\
\text { Females: PT/FT }\end{array}$ & 87.8 & 88.4 & 83.8 & 91.8 & 0.6 & -4.0 & 4.0 \\
\hline wage ratio & 103.0 & 99.6 & 99.6 & 103.7 & -3.4 & -3.4 & 0.7 \\
\hline
\end{tabular}

Notes: GWR = gender wage ratio; PT = employed part-time; FT = employed full-time. 
Turning to the other relativities reported in Table 4 it is clear that wage and compositional effects underpin the observed outcomes. For example, the gross wage ratio of women employed part-time relative to men employed full-time (the benchmark group) is equal to 88.4 per cent in 1998, a 0.6 percentage improvement on the 1990 rate (equal to 87.8 per cent). If rates of return had been held constant the composition effect would have seen the gap fall by 4.0 percentage points to 83.8. If the workforce composition had been held constant the wage effect would have delivered a 4.0 percentage point convergence in this relativity. As it was the two forces balanced each other out and the overall female part-time / male full-time gap remained relatively constant.

In the case of the male part-time / male full-time relativity the large deterioration in this gap (from 95 per cent to 85.3 per cent between 1990 and 1998) has been driven by compositional changes. Male part-time workers in 1998, on average, posses less education and lower experience levels than their 1990 counterparts. The influx of less qualified and experienced men into part-time employment also fully accounts for the convergence in the gender wage gap in part-time work. Whilst the entry of teenagers would lower the average experience rates, it is noteworthy that more recent male entrants into part-time employment are from older age groups; 35-59 year olds in particular (see Table 5), with many of them moving into casual jobs (i.e. jobs without leave entitlements) (Preston 2001b).

TABLE 5

Australian Part-Time Employment Shares and Growth Rates by Age and Sex November 1994 to November 2002

\begin{tabular}{lcccc}
\hline \multicolumn{3}{c}{ Males } & \multicolumn{2}{c}{ Females } \\
\hline & $\begin{array}{c}\text { Share of Part- } \\
\text { Time Work: }\end{array}$ & $\begin{array}{c}\text { Share of } \\
\text { \% Change } \\
\text { Part-Time } \\
\text { Age }\end{array}$ & Nov.02 & $\begin{array}{c}\text { \% Change } \\
\text { Nov.94- }\end{array}$ \\
\hline $15-19$ & 18.9 & 41.9 & 9.8 & 51.5 \\
$20-24$ & 16.0 & 57.2 & 10.1 & 44.7 \\
$25-34$ & 16.6 & 70.6 & 17.7 & 15.0 \\
$35-44$ & 15.3 & 88.5 & 27.7 & 21.4 \\
$45-54$ & 13.5 & 86.7 & 23.6 & 58.9 \\
$55-59$ & 8.8 & 120.2 & 7.0 & 118.7 \\
$60-64$ & 5.9 & 65.7 & 2.8 & 103.1 \\
65 and & & & & \\
Over & 4.9 & 20.4 & 1.3 & 46.5 \\
Total & 100.0 & 66.0 & 100.0 & 38.9 \\
Source: ABS unpublished data available from ABS Space-Time Research, Data Cube q2_aug94.srd &
\end{tabular}

The consistent story in all of this is that, net of compositional effects, the wages of men employed full-time have lost ground relative to target equity groups: women employed full-time; women employed part-time and men employed part-time. Why would wage growth amongst men employed full-time fail to keep up with growth rates experienced by these target equity groups? When considered against the data in Table 1 showing that women and part-timers are more likely to have their wages set by Awards than men in 
full-time work, and considering the significantly lower wages growth in the Award stream, the outcomes are even more puzzling.

The results may, as noted above, reflect data limitations. If the derived hourly wage in this study overstates the rate for women and part-timers (because of unaccounted shift loadings perhaps) and, similarly, understate the rate for men employed full-time (perhaps because of remuneration deals which see them being paid a portion of their income in the form of non-wage benefits), this might explain why wages of the latter have apparently lagged behind other groups. The data preclude further testing of this hypothesis, although it is clearly an avenue for future research. Moreover, the importance of this puzzle for many economic studies should not be overlooked. Surveys and models similar to those employed in this paper are at the core of many policy papers, such as those estimating the rates of return to higher education (e.g. Borland, Dawkins, Johnson, and Williams 2000).

A search of the literature suggests some other potential explanations for the apparent slower wage growth rate amongst men employed full-time. The first concerns substitution effects. If women are increasingly substituted for men this would raise the relative wages of women and lower the relative wages of men, although it would not account for the faster wage growth amongst men employed part-time. The patterns may, of course, reflect the results of decades of pay equity initiatives, including EEO legislation and job evaluations. Various submissions to the recent New South Wales Pay Equity Inquiry (for a summary see Pocock 1999) would, however, suggest otherwise.

Two other, related, contenders not yet mentioned include deunionization and the decline in public sector employment. Blau and Kahn's (1997: 31), for example, show that convergence in the US gender wage gap over the 1980s could be partly explained by the negative effects of deunionization on male earnings relative to female earnings. In Bell and Ritchie's (1998: 345) study of the changing gender wage gap, a faster rate of decline in the male public sector pay premium relative to the female public sector pay premium contributed to a convergence in the UK gender wage gap.

Due to data limitations it is beyond the scope of this paper to test these alternative hypotheses. However, it is noted that within Australia male union membership rates have declined the most. Between 1992 and 2000 male membership rates fell by 17.1 percentage points (to 26.3 per cent); the corresponding decline for females was 12 percentage points (to 22.8 per cent) (Preston, 2001b: 172). When read alongside the Peetz (2002) study on AWA penetration rates in unionised sectors, this deunionization hypothesis takes on even more appeal and is worthy of further investigation.

Perhaps consistent with the above, official data from the ABS may also support a sectoral hypothesis, although the effect might derive from a faster rate of decline in the male private sector pay premium. A plot of the average weekly ordinary time earnings for adult full-time employees, disaggregated by sector of employment (Figure 1) shows that relative to male public sector workers, the pay position of male and female private sector employees deteriorated over the period shown (August 1990 to May 2002). In the former the gap widened by 7.2 percentage points to 87.1 per cent by 2002; in the latter (female 
private / male public) the gap widened by 3.6 percentage points to 71.2 per cent by 2002 . The gender wage gap in the private sector, as a result, converged by 2.5 percentage points to 81.8 percent. Female public sector employees, in contrast, experienced a slight deterioration in their pay relative to their male public sector counterparts, with the public sector gender wage gap falling 1.4 percentage points to 86.7 per cent by 2002.

Figure 1

Australian Pay Ratios, by Gender and Sector, 1990-2002

(Average Weekly Ordinary Time Earnings, Adults, Employed Full-Time)

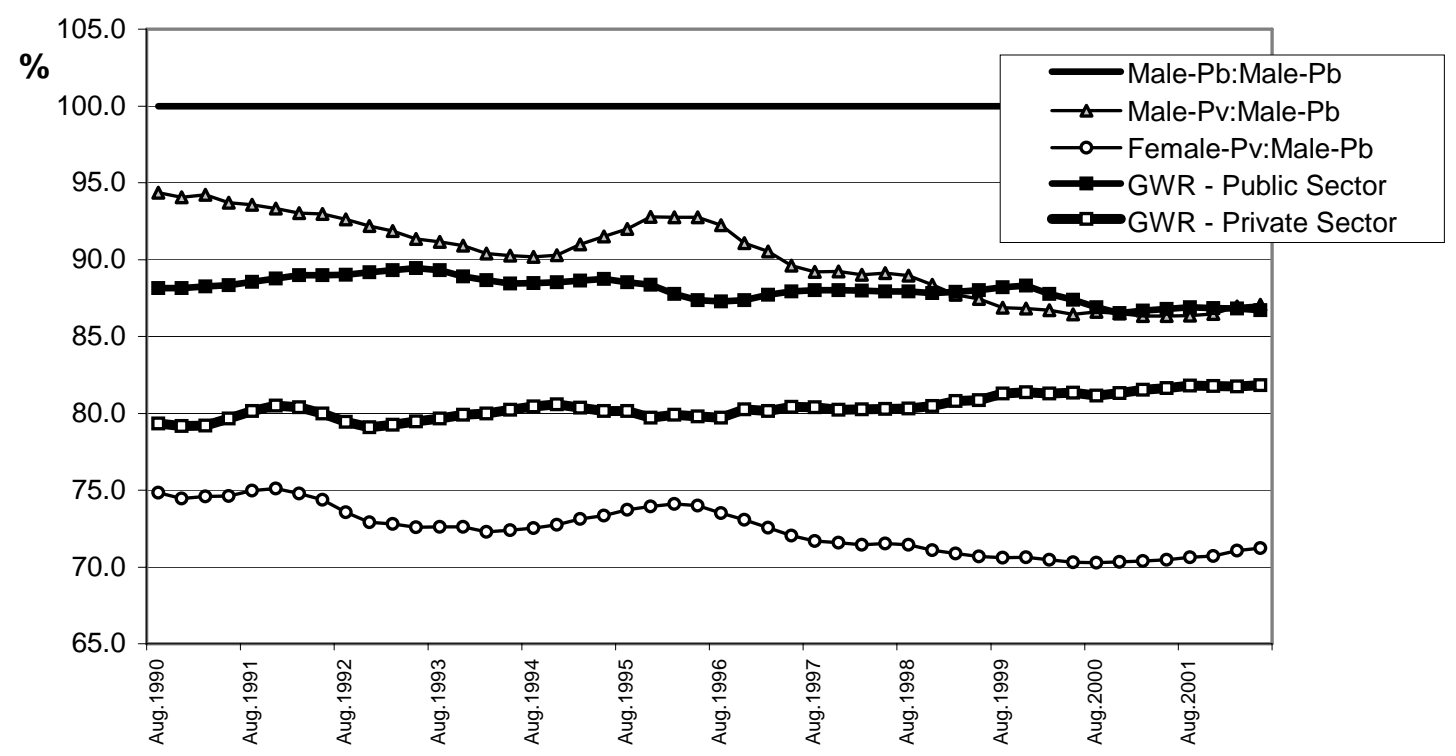

Source: ABS 630205; seasonally adjusted figures; estimates computed using a four quarter moving average; Note: $\mathrm{pb}=$ Public; $\mathrm{PV}=$ Private; $\mathrm{GWR}=\mathrm{Gender}$ Wage Ratio

\section{Summary and Conclusion}

As noted in the introduction several studies have demonstrated an important link between the size of the gender pay gap and prevailing bargaining arrangements, with centralized systems typically associated with smaller gaps. The shift towards a more decentralized wages system was, therefore, widely expected to negatively impact on the relative pay position of women and part-time workers when benchmarked against males employed full-time. In this paper data from 1989/90 (a period of highly centralized bargaining) and $1997 / 98$ are used to examine wage structure effects following radical changes to the Australian wages system in 1991. Contrary to expectations the results show that between 1990 and 1998 the adjusted gross gender wage ratio in the full-time labour market converged by four percentage points (to 88.8 per cent); in the part-time labour market the gender wage gap converged by 10.3 percentage points, delivering a wage advantage of 3.1 per cent. A decomposition to separate out composition effects and wage effects found that the observed convergence in the gender wage gap within the part-time sector 
derived from compositional effects, the entry of (on average) less qualified and less experienced males into part-time work.

In the full-time labour market the convergence could be attributed to wage effects, faster female wage growth relative to male wage growth. Indeed, males in full-time work have, over the 1990s, experienced substantially slower wage growth when benchmarked against all other target equity groups (women and part-time workers (male and female)). Data reported in Figure 1 suggests that this effect may be more pronounced amongst males employed within the private sector.

As with other similar studies, findings in this paper suggest a need to rethink what 'women's economic progress really means' - is it “women's gains or men's losses?” (Bernhardt et al. 1995: 205). Further research into the effects of deregulation and pay decentralization at different points in the skill distribution, together with an analysis of deunionization, sector effects, earnings of multiple-job holders and components in the remuneration packages of individuals would help further progress the gender gap debate in Australia.

Acknowledgements

I wish to thank John Burgess, Gillian Whitehouse, Keith Whitfield, Mark Wooden, Stephen Wood and participants in my session at the British University Industrial Relations Association Conference at Stirling University in 2002 for their comments. I thank Stirling University for hospitality whilst I was a visitor there. Financial support from Curtin University is similarly, gratefully, acknowledged. 


\section{References}

Australian Bureau of Statistics (2001) Employee Earnings and Hours, May 2000. Catalogue Number 6306.

Bell, D. and Ritchie, F. (1998) "Female earnings and gender differentials in Great Britain, 1977-1994”. Labour Economics, 5, 331-357.

Bernhardt, A., Morris, M., Handcock, M.S. (1995) “Women’s gains or men’s losses? A closer look at the shrinking gender gap in earnings". American Journal of Sociology, 101(2), 302-328.

Blau, F. and Kahn, L. (1992) “The gender earnings gap: learning from International comparisons”, American Economic Review, 82, 533-538.

Blau, F. and Kahn, L. (1996) "Wage structure and gender earnings differentials: an international comparison”. Economica, 63, S29-S62.

Blau, F. and Kahn, L. (1997) "Swimming upstream: trends in the gender wage differential in the 1980s". Journal of Labor Economics, 15(1), 1-42.

Borland, J., Dawkins, P., Johnson, D. and Williams, R. (2000) "Returns to Investment in Higher Education”. Higher Education Research Program, University of Melbourne, Research Report No. 1.

Bruegel, I. and Perrons, D. (1998) “Deregulation and women’s employment: the diverse experience of women in Britain”. Feminist Economics, 4(1), 103-125.

Creighton, B. and Stewart, A. (2000) Labour Law: An Introduction, The Federation Press, Sydney.

Deery, S., Plowman, D., Walsh, J. and Brown, M. (2001) Industrial Relations: A Contemporary Analysis, Second Edition (Reprinted 2002), The McGraw-Hill Company, Sydney.

Department of Employment, Workplace Relations and Small Business (DEWRSB) (2001). Safety Net Review - Wages, 2000-2001: Joint Governments’ Submission (The Commonwealth, The State of South Australia, The Northern Territory), Canberra.

Flanagan, R. (1999) "Macroeconomic performance and collective bargaining: an international perspective”. Journal of Economic Literature, 37, 1150-1175.

Gregory, R. and Daly, A. (1992) 'Who gets what? Institutions, human capital and black boxes as determinants of relative wages in Australia and the US'. Proceedings of the 9thWorld International Industrial Relations Association Congress, Sydney, Australia, 5, 79-106.

Le, A. and Miller, P. (2001) "The persistence of the female wage disadvantage” Australian Economic Review, 34(1), 33-52.

Miller, P. (1994) "Effects on earnings of the removal of direct discrimination in minimum wage rates: A validation of the Blinder decomposition”. Labour Economics, 1, 347-363.

Mincer, J. (1974) Schooling, Experience and Earnings, National Bureau of Economic Research, New York: Columbia University Press.

Peetz, D. (2001) "Individual Contracts, Collective Bargaining, Wages and Power” Australian National University, Centre for Economic Policy Research, Discussion Paper No. 347. 
Peetz, D. (2002) “Individual Contracts, Bargaining and Union Membership”. Australian Bulletin of Labour, Vol. 28(1), 39-52.

Pocock, B. (1999) "Introduction: what action now for pay equity”. Labour and Industry, 10(2), 1-8.

Preston, A. (1997) "Where are we now with human capital theory in Australia”. Economic Record, 73(220), 51-78.

Preston, A. (2001a) The Structure and Determinants of Wage Relativities: Evidence from Australia. Aldershot: Ashgate Publishing Limited.

Preston, A. (2001b) “The changing Australian labour market: developments during the last decade”. Australian Bulletin of Labour, 27(3), 153-176.

White, H. (1980) "A heteroskedasticity consistent covariance matrix estimator and a direct test of heteroskedasticity”. Econometrica, 48(4), 817-838.

Whitehouse, G. (2001) "Recent trends in pay equity: beyond the aggregate statistics”. Journal of Industrial Relations, 43(1), 66-78.

Whitehouse, G. (1992) "Legislation and labour market gender inequality: an analysis of OECD countries”, Work, Employment and Society, 6(1), 65-86.

Wooden, M. (1999) "Gender pay equity and comparable worth in Australia: a reassessment”. Australian Economic Review, 32(2), 157-171.

hierarchy

2 The hourly wage rate is derived as the common ratio of 'total current usual weekly income from wage and salary from main and second jobs' and 'number of hours usually worked per week in main and second jobs'. The hour data in the 1990 survey are grouped. The mid-point of each category was used to derive a continuous measure. The upper category (50 hours or more) was set equal to 52. In the 1998 data the open ended category of 50 or more was also set equal to 52.

$3 \quad$ It is acknowledged that assessment of women's relative earnings disadvantage via the inclusion of a dummy variable for gender does have its limitations such as constraining the estimates of the effects of schooling, labour market experience and other variables to be the same for both sexes. However, as Le and Miller (2001) note, it offers an expedient way of summarising the data. Secondly, and perhaps more importantly, the approach yields findings similar in magnitude to those obtained using more sophisticated approaches, such as the estimation of separate male and female wage equations and subsequent computation of an adjusted wage gap which is net of any 'explained' components (see Miller, 1994). A check was, nevertheless, undertaken. Using the dummy variable approach the estimated gender wage gap in 1998 in the full-time labour market is equal to 10.1 per cent. When separate male and female wage equations are estimated across full-timers and subsequently decomposed the 'unexplained' (ie. adjusted gender wage gap) is equal to 9.8 per cent. This finding is consistent with Miller (1994) and supports the use of the dummy variable approach. 